and prepared, the Service ration provides a good standard of feeding, paying full attention to nutritional problems and taste.

That it is so, can probably be deduced from the fact that the young recruit gains rapidly in weight and physique on joining the Services, and that, although we draw our recruits from all walks and conditions of life, malnutrition is almost unknown in the Services, despite the rigorous and difficult conditions under which men have to serve at all times and in all parts of the world.

\title{
The feeding of women in industry
}

\author{
By Phoebe Roscoe, Catering Manager, Glaxo Laboratories Ltd, Greenford, \\ Middlesex
}

Catering for workers in industry is easier in one way than catering for some other large groups of people. They only consume about half their daily food while at work, and their working week is frequently only 5 days out of the 7 . And they usually have a certain amount of free choice as it is very seldom now that industrial canteens and staff lunch rooms offer nothing but one fixed meal. So that there is no question of planning balanced menus for each day or week.

On the other hand, a very wide choice of different types of foods is now demanded by industrial workers in order to satisfy all their varied likes and needs. It is particularly noticeable when catering for staff of different types--factory, clerical and technical. And it is the women who want the greatest range of choice, especially at lunch time.

Many women, particularly those living alone and cooking for themselves, like to make their lunch the principal meal of the day, and will buy soup, a main dish, vegetables and a sweet. Others again like something slightly lighter with less substantial main dishes such as fish cakes, croquettes, cheese dishes, cold meats and salads. Some want just a snack of the egg on toast or Welsh rarebit type. And finally there are those, usually girls under 18 or 20 , who often have nothing more than a plate of chips. This choice appears to be partly because they want to spend as much of their lunch time as possible dancing or playing games, and partly because they don't want to spend much money on food. Like many industrial firms we give our adolescents a very cheap lunch. Juniors under 18 years of age can have a full three-course meal for only Is. od. Yet in spite of it many girls prefer to spend only $8 \mathrm{~d}$. or $9 \mathrm{~d}$. on a lunch of chips and ice-cream.

Slimming is a very important factor in influencing what the women eat, even amongst the teenagers. They buy far more salads than men, many fewer steamed and milk puddings, and much more stewed and tinned fruit. Their idea of what constitutes a slimming diet is apt to be rather curious. We often have women who cannot decide what dish to take because they say they are slimming. If you suggest that cold meat with green salad might be suitable the answer will often be: 'No, thank you. 
I think I'll just have a plate of chips'. (Incidentally, if I seem to mention chips rather often it is because, except for tea, they seem to be the most important single item in industrial catering!)

We find that most women, but particularly those working in the factory and starting work earlier than those in the offices and laboratories, buy themselves quite a good meal for their morning tea break in the form of buttered rolls or buns, or filled rolls and cheese, and drink a great deal of coffee-generally as milk with a dash of coffee for factory workers and with less milk for others. On the average they seem to buy more than the men, probably because most of them have so much to do at home before leaving for work that the majority of them have nothing for breakfast except a cup of tea. Most of the men, however, have had breakfast got for them at home, and many have also had sandwiches put up for their morning tea break so that they only buy a cup of tea or coffee. Quite a number of factory men also bring snacks for their midday lunch, supplementing these with soup or a pudding and a beverage. But few women, except some young ones with mothers to do it for them, have time for getting themselves either breakfast or packed snacks.

One reason why so many women want light or quick snack lunches is that they have to rush out in their lunch hours and do their domestic shopping, either because the shops are not open before or after work, or because they have to go straight home in the afternoon to see to children coming back from school and to prepare the evening meal. (It may be partly why they eat more cakes and the like in the afternoon tea breaks than the men.)

In our firm we find that the proportion of more substantial lunches sold is higher amongst clerical and technical staff than amongst factory staff. Possibly it is largely due to the former having their lunch breaks an hour later, but probably also to the fact that fewer of them bring in packed lunches.

Women are less conservative than men about what they eat and more enterprising in trying new dishes. They are also quick in comparing canteen charges with what they are paying in the shops. For instance, if eggs drop in price they tend to expect the canteen immediately to make a corresponding reduction in charge.

On the average many women spend more on their food than the men though they vary more from day to day. They will buy more of any special dishes put on the menu - the more expensive fishes, grills, fruits such as melon, strawberries and raspberries when in season, and fancy sweets, cakes and ice-cream, probably because many of them are married and look upon what they earn as extra pin money. They do not have to keep to such a fixed budget as the men and feel free to spend on these little extra luxuries. 